\title{
Managing the 1970s energy crises in a state-owned mining company: strategies pursued by the Swedish iron ore producer LKAB
}

\author{
Kristina Söderholm $^{1}$ (D) • Linus Larsson ${ }^{1} \cdot$ Patrik Söderholm $^{1}$
}

Received: 8 August 2017 / Accepted: 16 October 2017 /Published online: 30 October 2017

(C) The Author(s) 2017. This article is an open access publication

\begin{abstract}
In this paper, we analyze the strategies adopted by the Swedish state-owned iron ore mining producer LKAB in response to the 1970s energy crises, i.e., soaring energy input expenses in combination with stagnating demand for iron ore. The analysis builds on a unique empirical material, e.g., minutes from board meetings, over an extended time period. This permits in-depth analyses of the two main strategies pursued by LKAB at the time: (a) securing energy supplies (as well as output sales) through upstream investments in uranium and coal mining; and (b) engaging in own R\&D to enable energy-saving measures and product development. While the LKAB experiences tend to support the notion that investments supporting broader societal goals, although at the expense of firm productivity, may be likely in the presence of strong state government involvement, they also show that state-owned mineral enterprises can be highly innovative and competitive following investments in internal R\&D. Specifically, LKAB's R\&D contributed to significant product development and energy savings, the latter occurring both in the company's own pelletizing process as well as in the processes of key customers (i.e., the steel companies). The paper concludes by highlighting a number of important lessons for contemporary energy transitions in the process industries.
\end{abstract}

Kristina Söderholm

kristina.soderholm@1tu.se

1 Division of Social Sciences, Luleå University of Technology (LTU), 97187 Luleå, Sweden
Keywords Energy use · Oil crises · State-owned companies · Iron ore $\cdot$ Sweden

\section{Introduction}

Modern mining operations are energy-intensive. Today, the global mining industry accounts for more than one third of total industrial energy use and just above $10 \%$ of total final energy consumption (e.g., Guilbaud 2016). For this reason, it has been imperative for mining companies to identify and pursue energy-saving measures that make them less vulnerable to energy price increases without however jeopardizing the companies' overall competitiveness. The mining industry's ability to achieve this was particularly tested during the energy crises of the 1970. Energy — and in particular oil-prices soared, thus creating strong incentives for fuel substitution and reduced energy use in the industry. Moreover, with the advent of the first oil crisis in 1973-1974, global mineral demand stagnated (or fell) resulting in depressed prices. For instance, world iron ore exports tripled over the time period 1960-1974, but after that, it remained stagnant until the early 1990s (Rönnbäck 1992).

The strategies that were used by mining companies to address this dual challenge of high energy costs and low output prices in part differed depending on production technology, the mineral product, ownership pattern, national institutional environment, etc. In this paper, we take stock in Marian Radetzki's seminal work on the behavior and impacts of state-owned mineral enterprises 
(Radetzki 1985) and investigate the challenges faced and the strategies adopted by the Swedish state-owned iron ore mining producer LKAB during the 1970s energy crises. These crises were not only energy-related, but they also implied a general slump in steel and iron ore demand and a need for structural rationalization and product development in the industry (e.g., Ericsson and Isaksson 1981; af Geijerstam 1981). ${ }^{1}$ In this paper, however, we focus on the role of energy use and supply in this process.

We make use of a unique historical empirical material, minutes from board meetings, and company newsletters in combination with different secondary sources, over an extended time period. This permits in-depth analyses of the two main strategies pursued by LKAB in response to the crises: (a) securing the energy supplies (and output sales) through upstream investments in uranium and coal mining; and (b) engaging in own R\&D to enable energy-saving measures and product development. The investments in coal — and not least uranium - mining were in part also motivated for product diversification purposes.

By pursuing the above, the analysis adds to previous historical research on industrial energy use and the importance of energy efficiency for industry competitiveness. Economic historians have addressed the interplay between energy supply, energy use, and economic development, often noting that the transition to a fossil fuel-based economy was essential to the industrialization process and modern economic growth (e.g., Wrigley 1988; Pommeranz 2000; Kander et al. 2013; Rosenberg 1994). Historians of business and technology have in turn explored the entrepreneurship and the growth of major companies in the electricity and oil industries (e.g., Hughes 1993; Howarth et al. 2007; Chandler 1990; Jones 1981). The environmental impacts of energy production, not least in the oil industry, have also been subject to historical scrutiny (e.g., Sluyterman 2010; Gorman 2001). Nevertheless, although most business activities involve the use of energy and, since the early 1970s, changes in the relative prices of energy carriers, and energy policies have led to altered managerial conditions (Hoffman and Vantresca 2002); the strategies adopted by industry to address energy-related challenges have not been much explored by historians.

This pertains in particular to the mining and metal industry, ${ }^{2}$ where most previous work has been quantitative, i.e., estimating productivity trends and price responses (Henriksson et al. 2014;

\footnotetext{
${ }^{1}$ See also the special issue of Raw Materials Report (1981) on the rise and fall of Swedish mining. Notably, this issue reports on how the National Swedish Industrial Board (in June 1981) presented a rather gloomy picture of the future of iron ore mining in the country. Moreover, the prospects for LKAB improving its long-run relative cost situation were deemed to be limited.

${ }^{2}$ Bergquist and Söderholm (2016) provide an analysis of how the Swedish pulp and paper industry managed the transition away from oil and towards overall lower energy use following the energy crises during the 1970s.
}

Fang et al. 2009). Such research has however neglected the role of strategic decisions concerning energy use and efficiency at the company level as well as how these decisions have been influenced by market conditions, state involvement, and other contextual factors over time. This paper's focus on the strategies pursued by the Swedish state-owned iron ore producer LKAB during the energy crises is an attempt to partly fill this research gap.

The study of LKAB and the challenges this company faced during the 1970s energy crises is interesting for a number of reasons. First, it provides an interesting case of a state-owned enterprise managing to remain competitive in the iron ore market despite falling demand and soaring energy costs. ${ }^{3}$ LKAB was founded in 1890 and was nationalized already during the first decade of the 1900 s with $50 \%$ taken over by the state and with the right to buy the remainder of the shares at a later stage (e.g., Jonsson 1969). However, it lasted until 1957 until the state bought also these shares at a price agreed through negotiations. Thus, since this year, LKAB has been 100\% state-owned (Liedholm Johnson and Ericsson 2015). At the time of first oil crisis, LKAB was owned by Statsföretag AB, which had been formed in 1970 to govern the Swedish state's ownership of industrial companies. However, in 1983, due to the financial difficulties encountered during the recession in the late 1970s, the Ministry of Enterprise took over the direct responsibility of the country's capital-intensive process industries, including LKAB (Larsson et al. 2014) (see further below).

Still, while the LKAB experiences from the 1970s in part support the hypothesis that investments in projects that support broader societal goals but typically at the expense of firm productivity may be more prevalent in the presence of strong state involvement (see Radetzki 1985 and below), they also illustrate that even state-owned mineral enterprises can be highly innovative and benefit from substantial R\&D efforts. In other words, the character of the ownership may not be the decisive factor for a mining company's competitive strength, but rather the ways in which the ownership and the management of the mining operations are pursued.

Second, earlier research has illustrated how contemporary sustainability transitions can learn from examining the challenges encountered - as well as strategies employed - during earlier structural change processes (e.g., Meadowcroft 2011). During the 1970s, Swedish industry faced a need for modernization and structural rationalization, and similar challenges are faced today combined with a demand for higher energy efficiencies and the development of less carbon-intense technology (e.g., IVA 2013). Moreover, the 1970s was formative for industrial energy-related R\&D. The increased energy

\footnotetext{
${ }^{3}$ In 1975 , the company estimated the costs of oil to increase sevenfold if no action was taken to reduce oil dependence (minutes from LKAB's industrial council meeting, December 9, 1975, 7).
} 
prices had major impacts on countries' entire energy systems (Kander et al. 2013; McNeill 2000). Several industry strategies and policy instruments were implemented, thus providing opportunities for important lessons. In Sweden, the strategies adopted relied on a strong emphasis on the central state as an important driving force in the energy transition, e.g., in providing funding for development activities (Bergquist and Söderholm 2016). In other words, learning about the strategies pursued by LKAB to manage the oil crises of the 1970s should be of great interest for both contemporary policy makers as well as for representatives of energy-intensive industrial companies.

The paper proceeds as follows: In the next section, we briefly review the literature on the behavior and the nature of stateowned mineral enterprises. This is followed by a description of the methodology adopted, including the source material used. The empirical investigation is divided into four separate sections. The first provides a short technical background to the production processes of $\mathrm{LKAB}$, while the second summarizes the energyrelated activities of the company prior to the advent of first oil crisis in 1973. The remaining sections review and discuss the two main strategies used by LKAB to address the dual challenge of stagnating iron ore demand and soaring energy costs: securing energy supplies (and revenues) through energy supply diversification on the one hand and energy-saving measures and product development on the other. A final section concludes the paper.

\section{State-owned mineral enterprises: inefficient or innovative?}

Radetzki (1985) — and more recently Radetzki and Wårell (2017) - analyzes the importance of state-owned enterprises in the international mineral markets. These studies report and discuss the often sizeable shares of global production that these account for (see also Raw Materials Group 2011). In large parts, they also discuss the presence of significant differences in market behavior between state-owned companies and privately owned enterprises.

One of the most striking features of a state-owned enterprise is the presence of multiple objectives; the joint goals of profit maximization and operational efficiency are typically subordinated to the pursuit of a broader set of political goals and/or agendas (e.g., security of supply, regional development, job creation, satisfying the interest of powerful lobby groups, etc.). In terms of investment behavior, the government may require state-owned enterprises to pursue investments in projects that may not be commercially viable but that instead satisfy national strategic interests. This will risk crowding out more productive investment projects, thus reducing the overall profitability of the company.

This may impair the efficiency of the operations in a number of ways. Multiple goals make it more difficult to measure managerial performance, not least since these goals tend to be expressed in a blurred and unspecified manner. ${ }^{4}$ This is likely to lessen the pressure to minimize production costs and therefore also the search for efficiency improvements. An important aspect of this is the selection of top management; in the presence of political interference, such selection may be done less on the basis of managerial skills and instead on a desire to disseminate political favors (Radetzki and Wårell 2017). Several empirical studies support the notion that state-owned enterprises often have been less efficient than their private counterparts (Meggingson and Netter 2001; Schmitz 2004; Rosenberg 1994; Borcherding et al. 1982; Gillis 1980). Das (2012) has compared the performance of Indian mining ventures and concluded that in the non-metallic sector (coal, iron ore, etc.), the state-owned companies have only been half as productive compared to the privately owned enterprises.

However, the claim that state ownership of mining enterprises is a bad idea, and that it is impossible to combine with high productivity, has been questioned (e.g., Liedholm Johnson and Ericsson 2015). Such evidence, it is argued, has primarily been valid in the case of state-owned companies in the developing countries. The ultimate economic success of mining companies may however not be linked to the ownership per se, but rather to the way in which the owner operates. Even state-owned companies may act responsibly and refrain from losing sight of the long-term interest of the company (e.g., Ericsson 1996, Liedholm Johnson and Ericsson 2015). State-owned mining companies may also have a strong capital base, in turn facilitating long-term investments, e.g., through R\&D and pilot and demonstration activities. Furthermore, previous studies have indicated the difficulties encountered when comparing performances across companies, i.e., noting how different institutional settings and additional contextual factors often help explain why corporate strategies diverge (e.g., Mikler 2009; Gunningham et al. 2003; Wallace 1995). Ownership is therefore one out of many influencing factors and its role may be exaggerated unless these are also properly addressed.

The Swedish - and more broadly the Nordic - case is interesting in these respects. For instance, Hall and Soskice (2001) argue that business-state relations differed a lot between Sweden and the USA during the 1970s energy crises, i.e., with a tendency towards adversarial relations in the latter case and a model of political cooperation and active state intervention in Sweden (see also Bergquist and Söderholm 2016). The Swedish approach was underpinned by a corporative political culture from the 1930s and onwards. This built on consensus in the relationship between the government, industry, and interest groups, all essentially sharing the view

\footnotetext{
${ }^{4}$ Even if a specific goal has the highest priority at a certain point in time, the multi-objective nature of the state-owned firm gives the decision-maker a great deal of discretion. Put differently, it will be quite easy for the decision-maker to motivate decisions taken by pointing out a suitable goal, of which there are many to choose from (Vernon and Aharoni 1981).
} 
on the importance of technological development and productivity and that the Swedish welfare state should be built on industrial modernization (Rothstein 1992; Lewin 2002). This also affected the ways in which environmental regulations and energy policies were designed and implemented; reductions in industrial energy use as well as in air and water pollution would be achieved by the combined use of efficient regulations and public support to R\&D as well as by further developing (rather than dismantling) the existing industry structure (see also Söderholm et al. 2017).

In sum, the above leaves us with two partly contradicting hypotheses concerning the behavior and the performance of state-owned mineral enterprises, one emphasizing that state ownership could imply significant inefficiencies in the management of mining operations and the other essentially suggesting that ownership per se may not play a key role in how mining companies perform. The empirical material (see the next section) permits an in-depth analysis of what characterized the strategies and activities undertaken by a major Swedish state-owned iron ore company in response to the energy crises during the 1970 s.

\section{Methodology and empirical material}

The empirical analysis in the paper builds on the use of the qualitative historical case study method, primarily since this permits a context-rich assessment of how choices at the mining company level have been made in situations of uncertainty and mutual influence between the company and the central state. The process of dealing with soaring energy prices in a capital-intensive industry takes time; it takes place within specific actor networks and is shaped by the available technological knowledge at the time. An in-depth case study of the company LKAB over an extended time period permits us to better understand this context-specific process, i.e., the challenges faced and the solutions sought. Previous studies have shown that reduced energy use was one key to LKAB gaining stronger competitive strength in the early 1908s; its energy use was then only a third of that of some of the company's competitors (e.g., Raw Materials Group 1981). Still, few studies have analyzed at depth how the transition to lower energy use unfolded.

The LKAB case is also interesting given the role of the state as an owner. The policy documents underlying the initial establishment of Statsföretag AB in the early 1970s, i.e., government bills, emphasize that the Swedish state's influence on LKAB's operations (as well as those of the other affected industrial enterprises) was to be channeled through this company. While the legislation made clear that profitability and competitiveness in the market place are essential for industrial growth, it also stipulated that the state-owned enterprises had to address broader societal goals in their production and location decisions (Government Bill 1969:121). For instance, this implied that Statsföretag $\mathrm{AB}$ was responsible for appointing the board of LKAB and for the overall planning of the enterprises, in particular when it comes to new investments that could affect the structure of the industry and/or that were new to the industry. Still, the management of the operations as such was left to the company's CEO and its board.

The empirical analysis relies heavily on source material that has been gathered at LKAB's archive in Kiruna. It first of all consists of minutes from LKAB board meetings with associated appendices, as well as minutes (with appendices) from the company's industrial council meetings. During the 1970s and 1980s, LKAB's industrial council (företagsnämnd) was a body for information and consultation between company management and employees. The access to detailed information about the discussions taking place at the board meetings (as well as in preparatory meetings) is unique in business history studies, and it provides an opportunity to study company challenges and strategies chosen over time. The empirical investigation also builds on the consultation of the company newspaper, $L K A B$-tidningen ( $L K A B$ Times), and the company's information sheets, LKAB-nytt ( $L K A B$ News). These outlets were also gathered at LKAB's archive in Kiruna and function as supplementary sources of information. For an overview of the above-mentioned material, see Table 1.

The study primarily focuses on the time period 1973-1985 in order to form a picture of the various energy-related activities that the company undertook in response to the energy crises in the 1970s. However, after an initial review of the material, it was deemed necessary to investigate material also from earlier years, the reason being that some of the activities dated back to the mid-1960s (e.g., the focus on oil storage and exploration). For this reason, minutes from LKAB's board meetings starting already in 1971 have been studied and in the case of $L K A B$ Times, the material collection went as far back as 1964.

\section{LKAB — a brief technical background}

Ore has been mined in Sweden for more than a thousand years; besides iron, mainly copper, silver, and gold have been mined for long. The mines of LKAB are situated close to the Arctic Circle, nearby the towns Kiruna and Malmberget, and they are among the largest and richest iron ore (mainly magnetite) mines in the world. The LKAB process flow can (roughly) be divided into four main steps (see Fig. 1).

In the first step - the underground process - the solid ore is mined (about $1000 \mathrm{~m}$ below ground level), coarsely crushed, and transported from the mining area below ground level and up to the processing plants above ground. The three process steps above ground include sorting (dressing), concentration, and pelletizing. The sorting and concentration processes in turn consist of a number of sub-steps, the purpose of which 
Table 1 Empirical source material

Minutes from LKAB board meetings with attached appendices. Meeting location and dates

Stockholm December 16, 1974, § 82

Stockholm May 30, 1978, appendix 40

Stockholm April 26, 1979, appendix 20

Stockholm October 4, 1979, appendix 41

Kiruna September 4, 1980, appendices 30 and 32

Stockholm February 5, 1981, appendix 7

Malmberget June 12, 1981, appendices 18 and 19

Kiruna September 1, 1981, appendix 31

Stockholm September 7, 1982, appendix 9

Stockholm September 7, 1982, appendices 9, PM 1-2

Stockholm June 9, 1983, appendix 28, PM 1 and 3

Luleå December 15, 1983, appendix 67

Stockholm March 20, 1984, appendix 8
Minutes from LKAB's industrial council meetings

with attached appendices

Summary of minutes from the Kiruna and the Leväniemi's industrial councils' joint meeting in Kiruna, December 20, 1973

Meeting in Kiruna, March 26, 1974

Meeting in Kiruna, December 9, 1975

LKAB times, issues

1964, No. 4

1968, No. 1

1971, No. 2

1972, No. 2

1973, Nos. 1 and 4

1974, Nos. 2 and 4

1976, No. 1

LKAB news, issues

December 20, 1973

Source: The Company Archive of the LKAB Group, Kiruna, Sweden

is to reduce the particle size and separate out unwanted mineral grains to increase the iron content. The primary difference between the sorting and concentration stages is that the ore is rougher and dryer in the sorting process, while instead more finely ground and handled as water-based slurry in the socalled concentrating process. The reduction of particle size is achieved through various types of crushers and mills. In the concentration stage, flux material is also ground and mixed with the ground iron ore ("dressed ore") to achieve the desired product characteristics, i.e., chemical, mechanical, and metallurgical.

During the 1950s and 1960s, LKAB's final products consisted of fines (Hellmer 1996a). However, already in the 1950 s, the company decided to make use of - and further develop-new technology permitting first micronizing (milled) iron ore into fines (a powder), shaping these into spheres, and then heating the iron ore spheres into compact, high-grade iron ore pellets. This would provide LKAB with the opportunity to remove phosphorous compounds and facilitate transport to consumers. Iron ore pellets can withstand transport to the customers without breaking apart. During recent years, the main products for LKAB have been iron ore pellets for the production of iron in blast furnaces. Since a blast furnace needs to be fed with a certain particle size of ferrous material, the ore is pumped to the pellet plant for the next step in the process chain. Here, the ore (along with flux material, water, and binding agent) is rolled into "raw balls" which are then heated up in a pellet oven (Hallberg 2013).

The pellet plant is divided into a cold and a warm section. The cold section involves dewatering, addition of a binding agent, mixing, and cold rolling. The slurry is dewatered with large vacuum filters and then mixed with binding agent. The dressed ore is fed into large roll drums where it is formed into round balls. During the subsequent heat treatment in the sinter machine, a number of different metallurgical reactions occur, and at higher temperatures, the material in the balls sinters together, which reduces the inner porosity while increasing the strength of the ball. The sinter machine is divided into a number of zones with three different functions. These are drying, heating, and cooling, after which the product is ready for

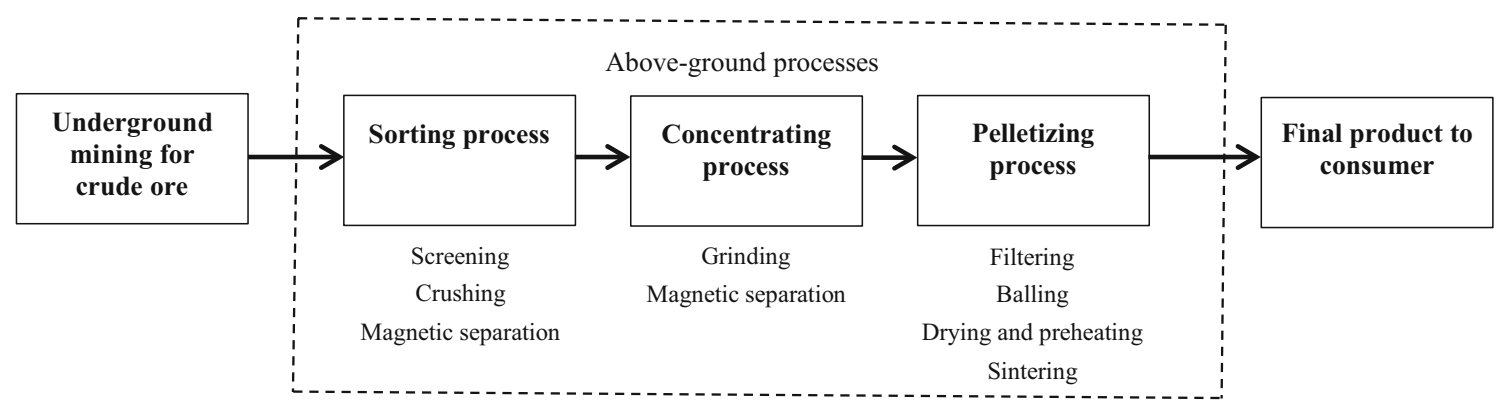

Fig. 1 The production processes of the Swedish iron ore producer LKAB. Sources: Lager et al. (2010) and LKAB website (www.lkab.com) 
transport and delivery to the customers (e.g., Lager et al. 2010; Hallberg 2013).

LKAB's production processes have over time been very energy-intensive, especially in terms of oil and electricity use. For instance, up until the mid-1970s oil use at the company's pellet plants could range between 20 and 301 per ton of pellets (e.g., Magnusson 2012a). As illustrated below, in response to the energy crises and the stagnation in iron ore demand during the 1970s, LKAB attempted two separate strategies to reduce its energy dependence as well as remain competitive in the global market. The first strategy—strongly endorsed and financially backed up by the Swedish state in the initial stages - was to secure energy deliveries (and revenues) through diversification to coal and uranium production. However, LKAB also made pioneering R\&D efforts to improve the quality of its products and lower the energy use of the company's - as well of its customers' - production processes (e.g., Rönnbäck 1992). In the end, this second strategy proved to be - by far - the most successful.

\section{Energy management at LKAB during the 1960s and early $1970 \mathrm{~s}$}

Given the importance of oil in LKAB's early production process, efforts were made to secure supplies in the case of interruptions (e.g., strikes) even before the advent of the energy crises. Already in the mid-1960s, LKAB built an oil storage facility to secure oil supplies for their planned pellet production increases (LKAB Times, 1964, $4: 22)$. A few years later, the company was involved in oil exploration activities initiated by the Swedish government. Oil and gas deposits had been discovered in Southern Sweden and at the bed of Baltic Sea, and the government hoped that these discoveries - if found to be economically exploitable - could help make the country less dependent on imports of fossil fuels. Apart from LKAB's own dependence on oil supplies, the involvement of the company in the exploration activities was motivated also by the company's expert knowledge on mineral processing and treatment. A number of private companies as well as the state-owned electric utility National Water Power Board (today Vattenfall) also participated in the exploration endeavors ( $L K A B$ Times, 1968, 1:3; LKAB Times, 1971, 2:3). In the early 1970s, the oil exploration was expanded to areas outside Sweden; one reason for this was that the exploration activities domestically had not achieved the desired results.

However, in 1972, the LKAB management team recognized that oil exploration could only be part of the solution ( $L K A B$ Times, 1973, 1:3). The global energy demand was rapidly increasing, and there were fears that oil production would not be able to keep up with this pace. Adding to the problematic picture for oil was the many conflicts in the part of the world where the greatest increase in the production of oil could occur, i.e., the Middle East. ${ }^{5}$ For LKAB, an oil crisis would have serious effects on the oil-dependent pellet production, which would become significantly more expensive and even be reduced in the event of an acute (physical) oil shortage (LKAB Times, 1973, 1:3). Also at this time, though, the state-owned company remarked that securing oil supplies was not only central to LKAB but also to the entire country (LKAB Times, 1972, 2:3).

With the so-called October War in the Middle East in 1973, the first oil crisis was a fact, and the concerns over the company's oil dependence became even more acute. Still, in the short-term, the situation was manageable, in part due to the company's oil storage facilities (LKAB Times, 1974, 4:3). ${ }^{6}$ Over the long-term, though, additional action had to be taken, and an immediate step was to initiate a so-called energy-saving group. This group comprised representatives from LKAB's various processes, a total of three full-time employees who would be completely dedicated to identifying future improvements in the energy conservation process. Specifically, the energy-saving group was assigned the task of investigating how LKAB could save on oil and electricity in a rationing situation, as well as how the company could reduce energy use through long-term investments.

In late 1973, the energy-saving group verified that the major energy users in LKAB's production processes were pressurized air, grinding, crushing, and pellet manufacturing. These could not become much more energy efficient in the short-term. Instead, recommendations were made to save on non-process energy use, such as lowering the temperature, turning off lights, heat fans, and ventilation and heating systems in offices when these were not in use. In addition, the company started to increase the shared use of vehicles, both above ground and in the underground mines. An energysaving campaign was also initiated where the employees could submit energy-saving suggestions for which they could also be rewarded.

In spite of these efforts, though, already in March 1974, the LKAB management team expressed that the energy issue had become a significant cost factor for the company. Not only had the direct costs for oil deliveries increased, but also electricity costs because a quarter of LKAB's electrical power was produced in oil-powered plants. ${ }^{7}$ In 1975 , LKAB projected that by 1980 , the total expenses for oil could have increased from SEK 20 million per year (in 1973) to about SEK 130 million (i.e., from about USD 4 million to USD 26 million). The corresponding costs for electricity could amount to SEK 170

\footnotetext{
${ }^{5}$ For instance, in 1972 , the LKAB management team noted that the American Secretary of State predicted an oil crisis in the USA and other industrial countries during the 1970s (LKAB Times, 1972, 2:3).

${ }^{6}$ Minutes from LKAB's industrial council meeting, December 20, 1973, 10.

${ }^{7}$ Minutes from LKAB's industrial council meeting, March 26, 1974, 11.
} 
million per year (compared to SEK 50 million in 1973). ${ }^{8}$ The dependence on oil in electricity generation thus made the task of making the pellet plants more energy efficient harder, this since at the time the only viable substitute to oil in the pelletizing processes was electricity. ${ }^{9}$ This motivated the company to pursue a strategy of diversification towards other energy sources such as coal and uranium and secure the supplies of these.

\section{Strategy \#1-securing energy supplies and sales through raw material diversification}

After 1974, there are only a few status reports in the source material related to oil exploration; instead the LKAB management now directed its attention to uranium and coal mining. The interest in nuclear power emerged already in 1973 ( $L K A B$ Times, 1973, 1:3). In the same year in December, LKAB become a partner in the so-called Ranstad uranium mine together with the National Water Power Board and AB Atomic Energy, ${ }^{10}$ and the plan was to resume extraction of uranium from alum shale. Uranium intended for the Swedish nuclear power program had been extracted there between 1965 and 1969. The mine had been built in the early 1960 s so that Sweden could be self-sufficient in terms of uranium, but as the price of uranium was too low, profitability in uranium mining could never be achieved during the 1960s (Holmstrand 2007). With the advent of the first crisis in 1973, however, the price of uranium soared and the mine was considered to become profitable. LKAB could contribute the necessary resources and knowledge to the project, because a large part of the problems connected with uranium exploitation concerned ore extraction and processing. In addition, uranium ore had been found in several other places in the country, including in the northern parts of Sweden where the LKAB iron ore mines were situated. ${ }^{11}$

LKAB became the primary shareholder in the Ranstad mine, and in 1975, it applied for a permit to resume operations. However, the project had to withstand harsh criticism from the local population and from environmental organizations, and several municipalities threatened to use their municipal veto. For this reason, LKAB withdrew the application; another permit was sought in 1977 but this application was also withdrawn due to renewed local opposition. In spite of this setback, though, the Swedish government still wanted to

\footnotetext{
${ }^{8}$ Minutes from LKAB's industrial council meeting, December 9, 1975, 7.

${ }^{9}$ Minutes from LKAB's industrial council meetings, December 20, 1973, 8 12, and March 26, 1974, 10. See also LKAB Times 1973, 4:3; and LKAB News, December 20, 1973.

${ }^{10} \mathrm{AB}$ Atomic Energy was a semi-government owned company founded in 1947 to explore and extract material for the utilization of nuclear power and to build nuclear reactors at the service of both research and industry.

${ }^{11}$ Minutes from LKAB board meeting, December 16, 1974, § 82, 6-7.
}

support R\&D work at the mine. The Parliament decided that the development work should continue at the Ranstad mine from 1978 to 1981 for the purpose of laying the groundwork for full-scale extraction. These R\&D efforts were entirely funded by government loans amounting to about SEK 126 million (about USD 30 million). Still, the plans for continued operations ceased; LKAB never managed to achieve the price agreements with the Swedish nuclear power industry that would have made the project economically viable. During 1981, the uranium mining plans were completely phased out. ${ }^{12}$

As the uranium project limped along in the late 1970s, LKAB - along with the Energy Commission of the government ${ }^{13}$ - decided that the use of coal should increase in Sweden during the 1980s. Coal had dominated Swedish energy supply during the first half of the twentieth century and was still an energy source that was widely available in the global market. The Energy Commission suggested that by 1990, coal could replace a full $40 \%$ of the current (1977) oil used in Sweden, primarily in nuclear heating plants but also to a certain extent in hot water centers as well as in industry. ${ }^{14} \mathrm{In}$ May 1978, LKAB, the National Water Power Board and Sydkraft (electric power company owned by a number of municipalities in the south of Sweden) joined forces in the new 1-year project Coal Supply 90 ("Coal 90") for the purpose of investigating the future market prospects for coal in Sweden (e.g., coal supply potentials, logistics, environmental impacts, etc.). ${ }^{15}$

In addition to setting up contracts with suppliers, LKAB also saw business openings in terms of direct involvement in owning and operating coal mines. Diversifying into coal made sense in that LKAB had considerable mining and transport knowledge; the management also saw possibilities for technology spin-offs. Nevertheless, a number of uncertain factors were identified, such as long lead times for establishing new mines and railways, the environmental impacts of coal incineration, as well as the future price developments in the global market for coal. Moreover, the profitability of future coal investments depended on state support.

Despite these economic risks, though, in 1979, the Coal 90 project presented results that confirmed that increased use of low-sulfur coal could be a viable option for Sweden (and for LKAB). In parallel with the Coal 90 project, LKAB had also made preparatory work to start up a coal company (see further below); this included communications with Poland, USA, and Australia concerning trade in coal. The prospects for being

\footnotetext{
$\overline{12}$ Minutes from LKAB board meeting, September 4, 1980, Appendix 32, 13.

${ }^{13}$ The Energy Commission represented Sweden's first government energy policy inquiry. It was appointed in 1976 with the task to present a comprehensive basis for the country's energy policy in the 1980s (Government Bill 19781979:115).

${ }^{14}$ Minutes from LKAB board meeting, May 30, 1978, Appendix 40, 1. See also Government Bill 1978-1979:115.

${ }^{15}$ Minutes from LKAB board meeting, May 30, 1978, Appendix 40, 1-3.
} 
involved in the operation of coal mines in the USA, Australia, and Canada were also addressed. ${ }^{16}$

Thus, in 1979, the mood was overall positive in LKAB's management team concerning involvement in coal. This was believed to be the only realistic possibility to reduce the oil dependency of the company. Coal was even judged to be superior to oil in certain application areas. Now, LKAB also conducted $R \& D$ in the area of coal purification; different qualities of coal were tested for the existing incineration technology. These activities were considered to play an important role also for the marketing of any extracted coal. LKAB was engaged by a number of government agencies, such as the Oil Replacement Delegation's Coal Group, the National Industrial Board, the National Water Power Board (project on coal, health, and environment), as well as by the international World Coal Study (WOCOL). ${ }^{17}$ In addition, the Swedish Coal Consortium examined a possible continued cooperation between LKAB, the National Water Power Board, Sydkraft, the state-owned steel company SSAB, and now also Stockholm Power Plant. The main objective was to form a joint coal company that could assist in securing the energy supplies of Sweden. ${ }^{18}$

LKAB's further engagement in coal was however dependent on the outcomes of the upcoming national referendum on nuclear power. This referendum took place on March 23, 1980 with the result, in brief, that the six nuclear reactors then in operation in Sweden could still be used and six additional reactors could be put into operation. ${ }^{19}$ However, the votes also suggested that in the future, nuclear power would be phased out. Following the referendum, LKAB's confidence in future coal investments increased, and it was deemed motivated to invest long-term in the coal market. Such an investment would also increase the security of Swedish energy supply, something which the board thought would help attract government funding to the company's coal projects.

LKAB's board argued that more capital and risk exposure would be required; new capital had to be allocated to the new subsidiary, LKAB Kol AB. The board also anticipated that state subsidies would soon "pour in" for coal exploration and to cover other preparatory costs. Awaiting a decision by the Parliament on this, the board envisioned that LKAB would invest internally generated funds in the subsidiary so as not to delay the ongoing search for interesting coal mining projects. The board also

\footnotetext{
${ }^{16}$ Minutes from LKAB board meeting, April 26, 1979, Appendix 20, 1-3. ${ }^{17}$ WOCOL was organized in 1978 by Carroll L. Wilson, Massachusetts Institute of Technology (MIT), to assess the potential of coal for meeting world energy needs up to the year 2000 (Wilson 1980).

18 Minutes from LKAB board meeting, October 4, 1979, Appendix 41, 1-8.

19 After the referendum, the Parliament decided that all nuclear reactors would be phased out by 2010 . However, today, in 2018, this is no longer imminent. Thus, it is now allowed to build new reactors to replace the ones currently in operation (at the existing sites).
}

decided that the company should enter the Swedish Coal Consortium as one of four partners. ${ }^{20}$

During the following winter (1980-1981), LKAB's board made a request to Statsföretag $\mathrm{AB}-\mathrm{a}$ government entity formed in 1970 for the purpose of taking care of the bulk of the state-owned companies - to place SEK 50 million (about USD 10 million at the time) for LKAB Kol's capital needs. ${ }^{21}$ However, only a few months later, in the summer of 1981, LKAB's board was forced to let loose of the coal plans. For the sixth consecutive year, the company reported negative operating profits, ${ }^{22}$ and the board had to prepare an action plan to come to terms with the economic problems. The board decided that all non-iron ore activities should be reviewed and evaluated, and that all development efforts in the energy and mineral areas had to be funded through special grants from the government in order to proceed. ${ }^{23}$ As far as the involvement in coal was concerned, the board assessed that this endeavor would require a significant addition of capital but the prospects for government funding were now judged to be bleak. The exception was exploration activities where the government offered favorable loans and funding of up to $50 \%$ of the costs. For the above reasons, the board of LKAB decided that the planned coal mining operations should be phased out. ${ }^{24}$

Thus, in the end, the strategy of diversifying into other energy sources such as nuclear power and coal mining did not prove successful for LKAB in spite parts of it being backed up by the government. ${ }^{25}$ Part of the reason for this was that diversification could alone not solve the dual challenges of soaring energy costs and the lack of competitive strength following the decrease in iron ore demand.

\section{Strategy \#2-energy-saving measures and product development}

As was noted above, with the advent of the first oil crisis in 1973, LKAB focused on various short-term measures to reduce energy — and in particular oil—use (e.g., linked to transport needs below and above ground and to ventilation and heating systems). The oil use taking place in the major production process such as in grinding, crushing, and pellet

\footnotetext{
${ }^{20}$ Minutes from LKAB board meeting, September 4, 1980, Appendix 30, $1-$ 3.

${ }^{21}$ Minutes from LKAB board meeting, February 5, 1981, Appendix 7, 5 .

22 The company reported negative operating profits during the period 1976 1982 (Hellmer, 1996a), and in 1981, the operating profits was SEK 218 million, i.e., about USD 50 million (minutes from LKAB board meeting, June 12, 1981, Appendix 18, 1).

${ }^{23}$ Minutes from LKAB board meeting, June 12, 1981, Appendices 18 and 19.

${ }^{24}$ Minutes from LKAB board meeting, September 1, 1981, Appendix 31, 3 4.

${ }^{25}$ It is worth noting that during the 1990 s, many specialist mining companies - many of them iron ore producers such as Rio Tinto, moved into coal mining. The growth of these companies in coal was primarily achieved by a combination of mergers and acquisitions (Humphreys and Welham 2000).
} 
manufacturing could however, it was argued, only be reduced following the initiation of intense development activities and investments.

In 1974, LKAB started to devote particular attention to the potential for oil savings in the company's pellet plants. The process engineers at LKAB made considerable efforts to improve the energy performance of the company's new pellet plant at the Malmberget mine. This was a so-called belt furnace plant; the investment commenced in 1973 and it took over 2 years to build. Magnusson (2012a) reports that the development efforts made at LKAB were pioneering; once in operation, the plant used $40 \%$ less oil than a conventional plant of the same type. Specifically, the new plant used about 101 of oil per ton pellets produced, while the corresponding number for LKAB's oldest plant at the time (built in 1955) was as much as 331 . The remainder of the company's pellet plants (in Kiruna and Svappavaara, respectively), both built in the late 1960s, used 16-17 1 of oil per ton (LKAB Times, 1974, 2: 19-20). The oil savings in the new pellet plant arose from having electrical fans convey the heat that was generated in the cooling zone back to the drying and heat zones. In conventional plants, most of the heat generated during the oxidation from magnetite to hematite instead went out through the smokestacks. ${ }^{26}$

In 1978, LKAB's research department initiated laboratory experiments for the purpose of creating an inexpensive and flexible pelletizing process, which was also energy efficient. The department developed a new process- the steel belt conveyor plant - in which the raw balls were baked on a perforated steel band with a bed layer of previously baked balls, to counteract over-heating of the steel band. The initial results proved very promising, and in 1980, the board approved the building of a pilot plant in Malmberget. The first test runs in the pilot facility during the winter 1981-1982 were successful, not least because they confirmed that the process would offer great potential for oil savings. ${ }^{27}$ Specifically, oil use in the pellet plant could be reduced to about 41 per ton pellets produced compared to about 61 in other modern pellet plants. Also, the electricity use was no higher than that in conventional plants. ${ }^{28}$

The new process was not only more flexible than its predecessors: it was also possible to achieve profitability at smaller scales of production albeit with a maintained high quality of the pellet. The results from the pilot tests brought the attention of Swedish and international industry, and the LKAB board deliberated on the prospects for commercializing the process. North America was deemed to be a particularly interesting

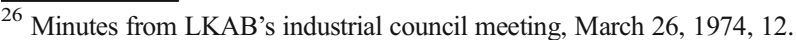

${ }^{27}$ Minutes from LKAB board meeting, September 7, 1982, Appendix 9, 1.

${ }^{28}$ Minutes from LKAB board meetings: September 7, 1982, Appendix 9, PM 1; and in June 9, 1983, Appendix 28, PM 3.
}

market; here, many old and energy inefficient pellets plants with high production costs were operating. ${ }^{29}$

Besides the fact that small-scale pellet production could be an interesting market niche for the company, it also offered LKAB the possibility of producing and testing pellets of several different qualities. In 1983, the board decided to launch a more long-term investment, which in part included the building of a commercial-size reference plant. This facility would not only be used for the purpose of exploiting the steel band process; the determined aim was also to increase the conditions for the company to mobilize and maintain a technical head start in pelletizing, as well as the competence and the capacity needed to develop and offer new products and technologies to the customers, i.e., primarily the blast furnaces of the steel industry. ${ }^{30}$ Product development was in line with LKAB's general strategy to get out of the long-lasting economic crisis, i.e., through a conscious shifting of the focus from the mine operations to the processing stages. The motto of LKAB became "Quality is our weapon," and this strategy helped the company to produce more highly valued products while at the same time reducing the dependence on oil and other energy carriers.

The product development activities of LKAB had gained considerable pace already during the mid-1970s. In spite of the tough market situation during the two oil crises, the company maintained high levels of $R \& D$ efforts. The intense focus on $R \& D$ and product development in the pellets sphere showed results, and in 1982, the company introduced the socalled olivine pellets. ${ }^{31}$ The development activities were performed jointly with the Swedish steel producer (SSAB). Olivine pellets could be produced by concentrating the easily enriched magnetite ore to a very high level of iron content, and then adding olivine, a magnesium-rich mineral (Rönnbäck 1992; Hellmer 1996b). This new product required lower energy use during the actual manufacturing process (Berger 2011). Aswathanarayana (2012) concludes that during the period 1970-2000, total energy use at LKAB's pellet plants was reduced by almost two thirds.

Furthermore, and equally important, the introduction of olivine pellets led to substantial efficiency advantages in LKAB's steel mill customers' production processes, i.e., in the blast furnaces. The attractiveness of the olivine pellets lies

\footnotetext{
${ }^{29}$ Minutes from LKAB board meeting, September 7, 1982, Appendix 9, PM 2.

${ }^{30}$ Minutes from LKAB board meetings: June 9, 1983, Appendix 28, PM 1; December 15, 1983, Appendix 67; and in March 20, 1984, Appendix 8.

${ }^{31}$ During the 1990s and onwards, LKAB continued to focus on product development and advanced product lines. For instance, during the 1990s, the R\&D budget could amount to $3 \%$ of the total turnover, resulting in metallurgical labs, and pilot plants for experimentation in beneficiation and pelletization (Rönnbäck 1992). Ericsson (1992) remarks that the attention devoted to $\mathrm{R} \& \mathrm{D}$ within $\mathrm{LKAB}$ has been among the highest in the global iron ore business. See also Lager et al. (2010) and Zuo and Hallin (2012) for reviews of the more recent product development activities taking place at LKAB.
} 
in its ability to retain a porous structure in the reduction process. This leads to high reducibility and a narrow melting, in turn yielding high productivity and substantially reduced energy use in the blast furnaces. ${ }^{32}$ Specifically, in the blast furnace, an important step towards lower energy use has been to reduce the amount of slag, and this was made easier with the introduction of olivine pellets. For instance, slag volumes at the SSAB steel mills almost halved after the introduction of the new product in 1982 (Rönnbäck 1992). In addition, the high-temperature durability of the olivine pellets also helped improve the blast furnaces' productivity in general and energy efficiency in particular (Magnusson 2012a).

In the end, product development-and thus not diversification into new raw materials such as uranium and coal-was LKAB's key for overcoming the economic and energy-related crises during the 1970s. ${ }^{33}$ This product development was highly relevant also from an energy perspective and implied both direct and indirect energy efficiency improvements. During the 1980s, LKAB adopted a rather aggressive pricing policy (i.e., offered a relatively low price premium) to establish its new products in the market and gain acceptance for olivine pellets as a superior substitute to sintered fines. The impact on sales was quick; already in 1983, the company reported an operating profit of SEK 295 million (about USD 70 million). Two years later, LKAB's profits were close to SEK 2500 million (Jansson Myhr 2015).

\section{Concluding discussion}

The purpose of this paper was to analyze the strategies pursued by the Swedish state-owned iron ore company LKAB during the 1970 s energy crises. The analysis illustrates how LKAB transformed from a supplier of standardized iron ore products sold at low margins in highly competitive markets, into a manufacturer of customized products tailored to buyers' specific needs, thus permitting premium prices and generating high returns on capital (e.g., Rönnbäck 1992; Magnusson 2012a). The energy supply diversification strategy did however not prove to be a success.

The empirical material illustrates the involvement of the state government in LKAB's deliberations and decisionmaking processes, at least in the case of the company's coal and uranium investment endeavors. For instance, the board meeting minutes show how national concerns about security were a key motive behind these investments. In addition, the

\footnotetext{
$\overline{32}$ Olivine pellets can also constitute $100 \%$ of the feed without impairing blast furnace efficiency, i.e., no mixing with other ferrous materials is needed (Magnusson 2012a).

${ }^{33}$ LKAB also developed new high-quality pellets for direct reduction (DR) processes, in this case with dolomite as binder (Hellmer 1996a). LKAB sales of DR pellets increased substantially after the turn of the twentieth century (e.g., Magnusson 2012b).
}

same material also illustrates how the company often expected the in-flow of public funding to improve the economic attractiveness of the projects. Hellmer (1996a) also reports how LKAB received significant amounts of government grants during the 1978-1982 period; these were aimed at letting the company write off some if the fixed assets, thereby reducing capacity.

Our analysis of LKABs involvement in the uranium and coal industries tends to support the hypothesis of state-owned mineral enterprises embarking on projects that may not have been entirely commercially viable. Thus, the more complex and diversified goal structure of state-owned companies compared to privately owned ones implies that the attention devoted to coal and uranium mining may have crowded out other more productive investments. ${ }^{34}$

However, our empirical results also show that even stateowned mining companies can be innovative and productive when permitted to invest in projects closely related to its core activities. Although LKAB was relatively closely tied to the central government in Stockholm (see also Liedholm Johnson and Ericsson 2015), in terms of iron ore mining/processing, the company was - and still is - managed very much as any other listed company. Its board of directors has been professional, and the company has typically been able to reinvest and secure enough internally generated funds when necessary. The R\&D efforts during the 1970s contributed to product development as well as energy savings, the latter both in the own process as well as in the blast furnace processes. In fact, LKAB's R\&D efforts have overall been more profound than those of most listed mining companies worldwide (Hitzman 2002; Ericsson 1996).

The LKAB case - and the focus on long-term technology development-is also not unique in these respects. For instance, from the 1980s and onwards, the Finnish stateowned company Outokumpu developed proprietary technologies (i.e., flash smelters), which could later be sold and licensed globally. In fact, both LKAB and Outokumpu have grown to become global leaders in their respective niches. Liedholm Johnson and Ericsson (2015) argue that the Norwegian experiences of state-owned coal mines in Svalbard provide another Nordic example that state ownership may be just as effective as any private ownership.

Our finding of R\&D-induced energy savings in the mining industry is also consistent with previous quantitative (econometric) research on the entire Swedish mining industry, thus also including also metals mining and processing. See Henriksson et al. (2014), although it should be noted that this work focused on the time period 1980-2010 during which the main attention was devoted to identifying improvements in the production processes' electricity efficiency (e.g., through the development of so-called process integration tools).

\footnotetext{
$\overline{{ }^{34} \text { Encouraging }}$ existing specialist mining companies to diversify away from their core activities is likely also an inefficient energy policy.
} 
Finally, this paper does also point towards a few generic lessons for future sustainability transitions in highly competitive process industries. In particular, attempts by the government to influence mining operations should primarily rely on regulations and economic instruments that are performance- rather than technology-based. This relates to the presence of companygovernment information asymmetries, that is companies know more about their production processes (and what can be altered at these) than the government. Performance-based policies (e.g., taxes on pollution and tax breaks for $\mathrm{R} \& \mathrm{D}$ expenses) make it easier for companies to experiment with different technological solutions and then choose the most efficient ones. This was clearly what happened in the transition away from traditional iron ore products to olivine pellets.

Moreover, R\&D investment is an essential strategy for managing long-run sustainability transitions in capital intensive processes. However, the LKAB case may not necessarily be representative in that global mining companies often are claimed to under-invest in R\&D. One reason for this is that mining processes typically consist of a large set of components and require the expertise of several companies to improve them, thus making it difficult to patent new innovations and more generally to avoid knowledge leakage to other companies. For this reason, public R\&D should perhaps play a more significant role in the mining industry than has been the case so far, at least for risky endeavors such as exploration activities and long-term knowledge development. However, the role of public R\&D support in the global mining industry, including the extent to which this differs across companies depending on ownership patterns, requires further scrutiny in future research.

\begin{abstract}
Acknowledgements The authors would like to thank LKAB for generously providing access to their company archive. The paper has also benefitted from valuable comments from Magnus Ericsson. Any remaining errors, though, reside solely with the authors.
\end{abstract}

Funding information Financial support from the Swedish Energy Agency (Grant No. 2015-002247) and Luleå University of Technology (Renewable Energy excellence area) is gratefully acknowledged.

Open Access This article is distributed under the terms of the Creative Commons Attribution 4.0 International License (http:// creativecommons.org/licenses/by/4.0/), which permits unrestricted use, distribution, and reproduction in any medium, provided you give appropriate credit to the original author(s) and the source, provide a link to the Creative Commons license, and indicate if changes were made.

\section{References}

af Geijerstam O (1981) Iron ore- a new world market? Raw Mater Rep 1(1):48-57

Aswathanarayana U (ed) (2012) Natural resources: technology, economics \& policy. CRC Press, Boca Raton
Berger A (2011) The rock and the roll - the green pellets story. LKAB Magazine 1:12-23

Bergquist A-K, Söderholm K (2016) Sustainable energy transition: the case of the Swedish pulp and paper industry 1973-1990. Energy Efficiency 9(5):1179-1192

Borcherding TE., Pommerehne WW, Schneider F (1982) Comparing the efficiency of private and public production: the evidence from five companies. Discussion Paper 8202, Institut für Empirische Wirtschaftsforschung, University of Zürich, Switzerland

Chandler AD (1990) Scale and scope. The dynamic of industrial capitalism. Harvard University Press, Cambridge

Das A (2012) Who extracts minerals more efficiently - public or private firms? A study of the Indian mining industry. J Policy Model 34(5): 755-766

Ericsson, M. (1996). Comment: The role of product differentiation in the iron ore industry: the case of LKAB (by Stefan Hellmer). Resourc Policy 22(1-2), 61-62

Ericsson M, Isaksson B (1981) Alternative futures for Kiruna. Raw Mater Rep 1(3):54-60

Fang H, Wu J, Zeng C (2009) Comparative study on efficiency performance of listed coal mining companies in China and the US. Energy Policy 37(12):5140-5514

Gillis M (1980) The role of state enterprises in economic development. Soc Res 47(2):248-289

Gorman HS (2001) Redefining efficiency: pollution concerns, regulatory mechanism and technological change in the US petroleum industry. The University of Akron Press, Akron

Government Bill 1969:121, On the establishment of Statsföretag AB, Stockholm

Government Bill 1978/79:115, On Guidelines for Energy Policy, Stockholm

Guilbaud JJS (2016) Hybrid renewable power systems for the mining industry: system costs, reliability costs, and portfolio cost risks. In: $\mathrm{Ph} . D$. University College London (UCL), Thesis

Gunningham, N., R. Kagan, and D. Thorthon (2003). Different shades of green. Business, regulation, and environment. Stanford University Press, Stanford

Hall P, Soskice D (2001) Varieties of capitalism: the institutional foundations of comparative advantage. Oxford University Press, New York

Hallberg D (2013) Termogravimetrisk analys av olika magnetitsliger från LKAB, Ph.D. Thesis, Luleå University of Technology, Sweden

Hellmer S (1996a) How LKAB gained competitive Strength. J Min Policy, Business Environ 12(4):2-14

Hellmer S (1996b) The role of product differentiation in the iron ore industry: the case of LKAB. Resourc Policy 22(1-2):49-60

Henriksson E, Söderholm P, Wårell L (2014) Industrial electricity demand and energy efficiency policy: the case of the Swedish mining industry. Energy Effic 7(3):477-491

Hitzman MW (2002) R\&D in a declining industry (mining): support for the development of revolutionary technologies? Technol Soc 24:6368

Hoffman AJ, Vantresca MJ (2002) Organizations, policy and the natural environment: institutions and strategic perspectives. Stanford University Press, Stanford

Holmstrand O (2007) Uran i Sverige. Nätverket Nejtilluranbrytning, Lerum

Howarth S, Jonker J, Sluyterman K, Luiten van Zanden J (2007) The history of Royal Dutch Shell. Oxford University Press, New York

Hughes TP (1993) Networks of power: electrification in Western society, 1880-1930. The Johns Hopkins University Press, Baltimore

Humphreys D, Welham K (2000) The restructuring of the international coal industry. International Journal of Global Energy Issues 13(4): 333-347

IVA (2013) Energieffektivisering av Sveriges industri. Hinder och möjligheter att nå en halverad energianvändning till 2050. Royal Swedish Academy of Engineering Sciences, Stockholm 
Jansson Myhr K (ed) (2015) The book of LKAB: 1890-2015. LKAB and the Centre for Business History, Stockholm

Jones G (1981) The state and the emergence of the British oil industry. Macmillan Press, London

Jonsson B (1969) Staten och malmfälten: en studie i svensk malmfältspolitik omkring sekelskiftet, Ph.D. Thesis, Uppsala University, Sweden

Kander A, Malamina P, Warde P (2013) Power to the people. Energy in Europe over the last five centuries. Princeton University Press, Princeton

Lager T, Hallberg D, Eriksson P (2010) Developing a process innovation work process: the LKAB experience. Int J Innov Manag 14(2):285306

Larsson M, Andersson-Skog L, Broberg O, Magnusson L, Pettersson T, Sandberg o P (2014) Det svenska näringslivets historia. Dialogos Förlag, Stockholm, pp 1864-2014

Lewin L (2002) Ideologi och strategi: svensk politik under 130 år. Norstedts juridik, Stockholm

Liedholm Johnson E, Ericsson M (2015) State ownership and control of minerals and mines in Sweden and Finland. Miner Econ 28:23-36

Magnusson M (2012a) The rolling stone. making LKAB's green pellets. LKAB Magazine 2:12-21

Magnusson M (2012b) Lysande utsikter för DR-pellets. LKAB Framtid $7: 6-7$

McNeill JR (2000) Something new under the sun: an environmental history of the twentieth-century world. W.W. Norton \& Company, New York

Meadowcroft J (2011) Engaging with the politics of sustainability transitions. Environ Innov Soc Trans 1(1):70-75

Meggingson WL, Netter JM (2001) From state to market: a survey of empirical studies on privatization. J Econ Lit 39(2):321-389

Mikler J (2009) Greening the car industry: varieties of capitalism and climate change. Edward Elgar, Cheltenham

Pommeranz K (2000) The great divergence. China, Europe and the making of the modern world economy. Princeton University Press, Princeton
Radetzki M (1985) State mineral enterprises. An investigation into their impact on the international mineral markets. Resources for the Future Press, Washington, DC

Radetzki M, Wårell L (2017) A handbook of primary commodities in the global economy, 2nd edn. Cambridge University Press, New York

Raw Materials Group (1981) LKAB — selling out forever? Raw Mater Rep 1(1):58

Raw Materials Group (2011) Overview of state ownership in the global minerals industry: long term trends and future. In: Extractive Industries for Development Series \#20. Washington, DC, The World Bank

Rönnbäck K (1992) Product development and competitiveness: the experience of LKAB. Resourc Policy 18(4):294-302

Rosenberg N (1994) Exploring the black box: technology, economics, and history. Cambridge University Press, New York

Rothstein B (1992) Den korporativa staten: intresseorganisationer och statsförvaltning i svensk politik. Norstedts juridik, Stockholm

Schmitz JA (2004) Privatization's impact on private productivity: the case of Brazilian iron ore. Research department staff report 337, Federal Reserve Bank of Minneapolis, USA

Sluyterman K (2010) Royal Dutch Shell: company strategies for dealing with environmental issues. Business Hist Rev 84:203-226

Söderholm K, Bergquist A-K, Söderholm P (2017) The transition to chlorine free pulp revisited: Nordic heterogeneity in environmental regulation and R\&D collaboration. J Clean Prod 165:1328-1339

Vernon R, Aharoni Y (1981) State owned enterprise in the Western economies. Croom Helm, London

Wallace D (1995) Environmental policy and industrial innovation. In: Strategies in Europe, the US and Japan. Earthscan, London

Wilson CL (1980) Coal-bridge to the future: a report of the world coal study. Ballinger Publishers, Cambridge, WOCOL

Wrigley A (1988) Continuity, chance and change: the character of the industrial revolution in England. Cambridge University Press, New York

Zuo G, Hallin M (2012) Iron ore product development at LKAB. Paper presented at the Asia steel international conference, 24-26 September, Beijing, China 